\title{
Labor, gender and governance in terms of establishment of new technological order
}

\author{
Liudmila Aleksandrovna Vasilenko ${ }^{1}$ and Sergey Vladimirovich Vasilenko \\ The Russian Presidential Academy of National Economy and Public Administration, Institute of \\ Public Administration and Civil Service, Moscow, Russia
}

\begin{abstract}
The prerequisites for the study are the transition of the world social system to the Technological Orders VI and VII in the context of a digital breakthrough and the hybrid nature of the digital social space, which significantly affects the change in the social structure, the distribution of social roles in society, the formation of the labor market and the formation of a new gender order. The purpose of the study is to analyze the impact of digitalization on the labor market, on the gender balance in the labor market and formulate how the processes of preparing a person for new technological structures should be built. According to the results of the study, the authors note that the formation of social institutions of a new type in a hybrid digital society significantly lags behind the need, digital regulators of social behavior in the labor market have not yet emerged, which does not allow building norms and rules of life in a virtual social space at the legislative level. The cognitive structures of society are immature, adequate incentives and sanctions as a response to the phenomena of crossing the boundaries of the office set framework by social actors have not been formed. There are no frameworks yet, but they can be created by maintaining a balance between the realization of society's needs for development and relying on its ability to maintain the stability of the value system, i.e. property of resistance.
\end{abstract}

Keywords: digital revolution, artificial intelligence, technological order, public administration, gender order, discrimination

\section{Introduction}

Technological Order - it is a set of technologies used at a certain historical stage in the development of production. The term was introduced by Academician D. Lvov and S. Glazyev. Modern transition to Technological Order VI and Technological Order VII at the global level, it is similar in scale to the previous technological transitions in the evolution of mankind - to agriculture, industrial production [1]. By 2010, the share of the productive forces of Technological Order V in developed countries was about $60 \%$, Technological Order IV - 20\%, and Technological Order VI - about 5\%. Technological Order VI is actively advancing almost today. Its main industries are nano- and biotechnology,

\footnotetext{
${ }^{1}$ Corresponding author: vasilenkola@mail.ru
} 
nanoenergy, molecular, cellular and nuclear technologies, nanobionics, nanotronics; use of stem cells, engineering of living tissues and organs, reconstructive surgery, digital medicine, new types of household appliances, transport, communications. The seventh order grows in the depths of the sixth, gradually forming the shoots of the future. The digital revolution is the most important component of the technical and technological conditions of the new order $[2,3]$. Its signs are the complication and hybrid nature of the digital social space, mediated by infrastructure, software and hardware, and the growth in the number of users of the global Internet. By the beginning of 2021, their number amounted to 4.2 billion people; 1.3 million people join social networks every day. Hybridity is expressed in the fact that users spend 3-4 hours a day on the Internet, including interactive viewing of TV broadcasts from tablets, mobile phones, laptops, personal computers, every 12 th person owns a smart speaker with a built-in microphone and a voice assistant working on based on artificial intelligence, a third use image recognition tools, 4 out of 10 female users have used an image as a search query [4]. The digital revolution is an important technical and technological condition for new structures, including the industrial Internet of things; virtual and augmented reality; IT solutions in the financial industry and law (blockchain, Smar contract); artificial intelligence (AI) and robotics, neural networks; digital medicine; 3D printing; Big Data, etc. New technological structures significantly change the organization of production and the essence of professional activity in the workplace. Talent management is in demand, which originates from the study "The war for talent" in 2000 [5], GALS technologies, creative industries [6], Agile technologies. In the new technological structures, the social structure, the distribution of social roles in society and the labor market are changing significantly. The breadth and fundamentality of education, the universality of qualifications and the ability to work in interdisciplinary teams in institutionally unformed environments, the ability to solve problems outside the box, and work with limited tools are becoming important.

\section{$2 \quad$ Methods}

\section{$2.1 \quad$ Technique}

Interaction in a common digital environment of many civilizational communities requires a revision of cultural universals that determine the degree of coherence of relationships [7]. The implementation of digital network platforms of the state expands the network interaction of the state with citizens, business associations and public organizations in all spheres of life. Out-of-state regulators, new local and global parameters of order are being formed. According to the UN approaches [8], it is necessary to create conditions for the full involvement of citizens and their associations in public administration, create network tools for expressing the interests, rights and obligations of citizens and their performance of management functions, and develop network digital institutions. This requires preparing a person for the future in conditions of uncertainty generated by two contradictory tendencies [9]: the desire to preserve the old way of life and the desire of individuals to develop (new, professions, lifestyle), sometimes reaching extreme forms of deviation, called by $\mathrm{F}$. Fukuyama phenomena spontaneous socialization, denoting the elements of a new order through the rejection of some of the traditional values [10].

In these conditions, Galina Sillaste puts forward the idea of a new gender order, understanding it as a social model of new norms, rules, principles of life and work, social and interpersonal interaction of the two largest socio-demographic communities: male and 
female, which are system-forming communities in the structure population of any state [11]. The ideological foundation is gender equality, in contrast to the model of equality of the status of men and women.

Does digitalization violate the equality of men and women in the labor market and how should the managerial processes of preparing a person for the future be built? It is undeniable that digitalization is changing the labor market. Old professions are becoming a thing of the past, mass layoffs of high and medium-level professionals in obsolete professions, "deprofessionalization", "skill mismatch", and "on-the-fly transformation" are expected. In Russia, 33.9 million people fall into the "skills mismatch" zone, when the professional skills of workers are either insufficient or excessive for the available vacancies. The number of traditionally female jobs is declining, but new opportunities (new specialties) are emerging that can provide employment gaps for women [12]. The problem of discrimination against women in employment in Russia is seen in terms of employers' use of masculine names of professions and descriptions of the proposed position. The problem can be solved by revising by key companies "their mission, social responsibility criteria and the style of posted vacancies with the probable use of verification using artificial intelligence programs" [13]. According to T. Shaulova, digitalization will transform not only the labor market, but also the mentality, and "artificial intelligence" demonstrates "partiality" in connection with the formulation of the problem "using machine learning methods, cognitive bias" at the stage of selecting criteria and inaccurate data into algorithms in period of study, i.e. possible "algorithm bias" is associated with "real world" bias [14]. Artificial Intelligence-as-a-Service (AIaaS) empowers individuals and organizations to access AI on-demand, in either tailored or 'off-the-shelf' forms. However, institutional separation between development, training and deployment can lead to critical opacities, such as obscuring the level of human effort necessary to produce and train AI services. Information about how, where, and for whom AI services have been produced are valuable secrets, which vendors strategically disclose to clients depending on commercial interests" [15].

\subsection{Empirical base}

1. Analysis of texts Russian media and Russian-language social media, analyzed 168 texts (UNIAN, TASS, Interfax, RBC-Ukraine, IA "Ukrinform", korrespondent.net, "Parliamentary newspaper", IA Reporter, IA Sputnik, zn.ua, IA Ukrainian News, MIA Russia Today, IA Bridge Dnipro, Rossiyskaya Gazeta, Izvestia, Deutsche Welle, gazeta.ua, znak.com, Komsomolskaya Pravda, Kommersant), containing the phrase "public administration" for the period from February 13, 2015 to February 13, 2020, using the Medialogy information system.

2. The problem of discrimination against women in employment in Russia. Poll in Stories [16].

3. Women Business Index (WBI) wave V. Conducted by the Analytical Center NAFI in partnership with Opora Rossii, the Agency for Strategic Initiatives and URALSIB Bank. 600 women who do not carry out entrepreneurial activity were interviewed (the sample is representative in terms of geography, age and type of settlement); 400 women entrepreneurs from eight Federal Districts (the sample of enterprises was built according to the indicators of the size and industry of Rosstat's business [17].

\section{$3 \quad$ Results and Discussion}


Features of the modern labor market:

1. An increase in the aging of the population associated with a significant increase in human life expectancy. Russian pensioners will make up $27 \%$ of the population by 2022 ;

2. Problems of employment, impossibility of self-realization, full-fledged life of pensioners and socially vulnerable groups of the population;

3. An increase in the number of divorced women by $6 \%$, the development of "virtual sex", the exaggeration of the rights to register same-sex marriages, a fashion for an extremely high level of material well-being and an unwillingness to combine the responsibilities of a mother and father with building a career, refusal to have children, since keeping children interferes with this;

4. M. Gray and S. Suri showed new forms of exploitation [18] - high-tech companies (Amazon, Google, Microsoft, Uber) exploit ghost work, creating a ghost economy. Freelancing attracts young mothers, early retirement professionals, and recent graduates. They cannot get a job with reliable guarantees of working conditions and are forced for little money to correct large volumes of publications of various formats from prohibited content on sites, etc. They do not have health benefits; they can be dismissed at any time, since there is not enough legislative regulation in this area today.

The topic of freelance work, self-employment, and "nomadic" labor resources in a digital society require legislative registration, since these trends become an objective basis for countering democratic processes and returning part of society to patriarchy. The incompetence of officials in the field of gender relations, the incorrect work of social institutions is dangerous for society. "The average salary of women in 2015 ranged from $68.3 \%$ to $82 \%$ of the salary of men". The idea of a higher status and more profitable position of men in a digital society leads to an increase in cases of gender reassignment by women, not for medical reasons, but for social reasons [19].

According to the International Economic Forum, from 2015 to 2020, men will lose about 4 million jobs, but get almost 1.4 million new ones, and women will lose 3 million jobs, and get about 550 thousand, the share of new professions by 2022 will grow to $27 \%$ [20], which may lead to gender asymmetry regarding professions classified as "male". Freelancing and STEM professions (science, technology, engineering and mathematics) are rapidly developing in 2018. Of the 4,777 employees and 367 employers of Russian organizations, $38 \%$ say that there are not enough professional candidates in the labor market; $46 \%$ note a shortage of specialists in new professions, and only $16 \%$ of respondents believe that there is enough qualified personnel. At the same time, it is noted: the lack of a full-fledged educational structure for the digital economy [21], the low number of women receiving STEM professions; problems of women's entrepreneurship in the field of information technology [22] and problems of perception of the digital world by women of different generations [23].

The authors also note the positive trends in the digital labor market:

1. Robotization and the use of artificial intelligence create a technological basis that allows women to perform former "heavy, male" activities,

2. An increase in the proportion of women in ICT in such professions as operator, software tester, content manager, consultant; it is predicted that gender inequality will be smoothed out in some industries, for example, in dairy farming and the dairy industry [24];

3. An increase in the number of freelancers in the field of online services and cryptocurrencies (digitizers, webmasters, miners, etc.);

4. Cloud-watchers who are able to improve themselves, work in different modes, make extraordinary decisions in non-standard situations and act with a limited set of tools are in demand in high-tech industries. 
In Russia, self-organizing processes of activity of women entrepreneurs are observed. For example, the WBI-5 Entrepreneurial Activity Index introduced an index of business readiness for the digital economy among women entrepreneurs (WBI). It amounted to 45 out of 100 items. $12 \%$ of women entrepreneurs sent their employees to IT training, $79 \%$ would like to have a mentor, $32 \%$ noted positive dynamics in their personal / family life (hobbies, sports, interests, travel). They see the problem in the insufficient representation of their business on the Internet $-40 \%$ do not have a website, $47 \%$ do not have pages in social networks, $27 \%$ maintain paperwork. $67 \%$ of non-entrepreneurial women consider starting a business, $64 \%$ would like to learn from well-known entrepreneurs.

In these conditions, the weakness of the institutions of socialization in a digital society is noted. The participation of civic organizations, the publicity of public administration in the context of digitalization is little covered in modern media. So, the only one of 168 articles in the regional press in five years (2016-2020 raises the problems of introducing an intelligent management system in public administration through the introduction of KPIs in rural administrations, expressing doubts: is it possible to increase the efficiency of public administration by technocratic methods, and what place should citizens in the public administration system [25]. It is necessary to monitor the gender structure of employment and the management of these processes, deprofessionalization processes. It is in demand to search for new models and drivers of development in the formation of appropriate qualifications, assessment and certification of specialists of a new format.

At the same time, the property of resistance is revealed in the virtual environment, the ability of society to preserve the value, worldview system in the format of the return of a part of the population to patriarchal relations. In the context of digitalization, the state as a platform, there is an effect of the primacy of the state and the secondary nature of the structures and organizations of civil society, the institutions of the state primarily do what contributes to the effectiveness of its own administrative structures. The issue of creating a civil society as a platform is out of the question.

\section{Conclusion}

In September 2018, at the Second Eurasian Female Forum [26], V. Putin emphasized the vital role of women in the modern world, noted the need to solve the problem of gender inequality, remove existing restrictions, create the necessary conditions for professional activity and doing business, provide ample opportunities for girls to receive education, but at the same time preserve the value of motherhood and a full-fledged family. Here, not only comfortable and comfortable conditions are important, ensuring the guarantee of legal and social protection so that a woman can feel independent and protected, but also the ability of all state and non-state actors to quickly and constructively master the incoming information, conditioning the organizational integration of the emerging complexity and ensuring the stability of the social system. In this regard, it is important to form a new concept of public administration, which should be based on the actor-network concept and ethics of digitalization, analysis of social networks, relational sociology, the concept of figuration and fractal-evolutionary concept, the concept of configuring the relational network of stakeholders [27].

The research is supported partially by Russian Fond for Basic Research, grant No. 20-011-00694 "Public Administration as Configuring of Relational Networks in the Public Space of a Digital Society". 


\section{References}

1. V.V. Glushchenko, Int J Sci Adv, 2(4), 554-563 (2021)

2. C.E. Shannon, W. Weaver, The mathematical theory of communication. (University of Illinois Press, Urbana, 1963)

3. M. Hilbert, L. Priscila, Science, 332(6025), 60-65 (2011). https://doi.org/10.1126/science.1200970

4. Digital 2021: Global Overview Report. Accessed on: October 4, 2021. [Online]. Available: https://datareportal.com/reports/digital-2021-global-overview-report

5. Ed. Michaels, H. Handfield-Jones, B. Axelro, The War for Talent. (Massachusetts Harvard Business School Press, Boston, 2001)

6. Kreativnyye industrii - sektor novoy ekonomiki [Creative industries - a sector of the new economy]. Accessed on: October 4, 2021. [Online]. Available:

http://uldelo.ru/2018/05/03/b-kreativnye-industrii--b-br-sektor-novoi-ekonomiki

7. L.A. Vasilenko, Tsifrovoe soobshchestvo i rasprostranenie novogo gendernogo poryadka [Digital community and dissemination of the new gender order], in $\mathrm{G}$. Sillaste (ed), Gender resources and the formation of a new gender order in the $21 \mathrm{st}$ century, 122-126. (Moscow, 2020)

8. Reconceptualizing Governance. (Management Development and Governance Division, Bureau for Policy and Programme Support, UNDP, New York, 1997)

9. L.A. Vasilenko, Soc Manag, 4(3), 45-56 (2018). https://doi.org/10.18413/2408-9338-2018-4-3-0-4

10. F. Fukuyama, Trust: The Social Virtue and the Path to Prosperity. (Free Press, New York, 1995)

11. G.G. Sillaste, Novyi gendernyi poryadok kak sotsialnyi fenomen epokhi globalizatsii $i$ ego rossiiskaya traektoriya [New gender order as a social phenomenon of the age of globalization and its russian trajectory], in G. Sillaste (ed), Gender resources and the formation of a new gender order in the 21st century, 18-29. (Moscow, 2020)

12. N.V. Nikiforova, Sci Notes Rus State Soc Univ, 19(4(157)), 69-76 (2020). https://doi.org/10.17922/2071-5323-2020-19-4-69-76

13. S.A. Anisimova, Problema diskriminatsii zhenshchin pri trudoustroistve $v$ Rossii [The problem of discrimination against women in employment in Russia], in Collection of articles of the International Scientific and Practical Conference: in 2 parts, 2021, Penza, January 23, 2021. (Science and Education, Penza, 2021)

14. T.V. Shaulova, Int Rel Dial Cult, 7, $42-54$ (2019)

15. G. Newlands, Big Data Soc, (2021). https://doi.org/10.1177/20539517211016026

16. @sofya_kings. Pools. Accessed on: October 4, 2021. [Online]. Available: https://www.instagram.com/s/aGlnaGxpZ2h0OjE3ODU1NTg0NDkzMzk0MzQw?stor y_media_id $=2477917158413655647$ 55447732\&utm_medium $=$ copy_link

17. Komitet po razvitiyu zhenskogo predprinimatelstva "Opora Rossii" [Committee for the Development of Women's Entrepreneurship "Support of Russia”]. Accessed on: October 4, 2021. [Online]. Available: https://www.womanopora.ru

18. M. L.Gray, S. Suri, Ghost Work: How to Stop Silicon Valley from Building a New Global Underclass. (Eamon Dolan Books, Boston, 2019) 
19. V.G. Ushakova, Tsifrovoe i (informatsionnoe) obshchestvo: gendernye aspekty [Digital and (information) society: gender aspects], in Gender Dimension of the Digital Economy: From Strategy to Action (2018-2030). Materials of the All-Russian conference with international participation. (2018)

20. The Future of Jobs Report 2018. Accessed on: October 4, 2021. [Online]. Available: https://www3.weforum.org/docs/WEF_Future_of_Jobs_2018.pdf

21. O.O. Korobova, Zhenskoe Predprinimatelstvo: Tsifrovye Biznes-modeli [Female Entrepreneurship: Digital Business Models], in Citizens and Citizens in the Political, Economic and Cultural Processes of Russian Urbanization in the XIV-XXI Centuries, 2, 18-21. Proc. XI Int. Scientific. conf. RAIZHI and IEA RAS, October 4-7, 2018, Nizhny Novgorod. (Moscow, 2018)

22. A. Larsson, Y. Viitaoja, Identifying the digital gender divide, in A. Larsson, R. Teigland (eds), The Digital Transformation of Labor: digest. (Routledge, 2019)

23. L.A. Gromova, L.S. Kiseleva, Woman Rus Soc, 3(88), 85-96 (2018)

24. M.N. Dudin, E.V. Levina, A.N. Anishchenko, Soc Labour Res, 38(1), 73-84 (2020). https://doi.org/10.34022/2658-3712-2020-38-1-73-84

25. Vrio gubernatora Lipetskoi oblasti planiruet vnedrit KPI v administratsiyakh selskikh raionov [Acting Governor of Lipetsk Region plans to introduce KPI in rural administrations]. Accessed on: October 4, 2021. [Online]. Available: https://www.kommersant.ru/doc/3764386

26. The Second Eurasian Women's Forum plenary session, Women for Global Security and Sustainable Development. Accessed on: October 4, 2021. [Online]. Available: http://council.gov.ru/en/events/news/96167/

27. V.V. Zotov, L.A. Vasilenko, Manag Consul, 5, 98-109 (2021). https://doi.org/10.22394/1726-1139-2021-5-98-109 